\title{
Anti-CTLA-4 Monoclonal Antibody
}

National Cancer Institute

\section{Source}

National Cancer Institute. Anti-CT LA-4 Monoclonal Antibody. NCI Thesaurus. Code

C128036.

Any monoclonal antigen ag ainst the antigen cytotoxic T-lymphocyte associated protein

4 (CT LA-4; CT LA4; CD152). 